\title{
QUEEN'S
UNIVERSITY
BELFAST
}

\section{Wind turbine noise}

Hanning, C. D., \& Evans, A. (2012). Wind turbine noise. British Medical Journal, 344(7853), 1-2. [e1527]. https://doi.org/10.1136/bmj.e1527

\section{Published in:}

British Medical Journal

\section{Document Version:}

Publisher's PDF, also known as Version of record

Queen's University Belfast - Research Portal:

Link to publication record in Queen's University Belfast Research Portal

\section{Publisher rights}

(C) BMJ Publishing Group Ltd 2012. This work is made available online in accordance with the publisher's policies. Please refer to any applicable terms of use of the publisher.

\section{General rights}

Copyright for the publications made accessible via the Queen's University Belfast Research Portal is retained by the author(s) and / or other copyright owners and it is a condition of accessing these publications that users recognise and abide by the legal requirements associated with these rights.

\section{Take down policy}

The Research Portal is Queen's institutional repository that provides access to Queen's research output. Every effort has been made to ensure that content in the Research Portal does not infringe any person's rights, or applicable UK laws. If you discover content in the Research Portal that you believe breaches copyright or violates any law, please contact openaccess@qub.ac.uk. 


\title{
Wind turbine noise
}

\author{
Seems to affect health adversely and an independent review of evidence is needed
}

\section{Christopher D Hanning honorary consultant in sleep medicine ${ }^{1}$, Alun Evans professor emeritus ${ }^{2}$}

${ }^{1}$ Sleep Disorders Service, University Hospitals of Leicester, Leicester General Hospital, Leicester LE5 4PW, UK; ${ }^{2}$ Centre for Public Health, Queen's University of Belfast, Institute of Clinical Science B, Belfast, UK

The evidence for adequate sleep as a prerequisite for human health, particularly child health, is overwhelming. Governments have recently paid much attention to the effects of environmental noise on sleep duration and quality, and to how to reduce such noise. ${ }^{1}$ However, governments have also imposed noise from industrial wind turbines on large swathes of peaceful countryside.

The impact of road, rail, and aircraft noise on sleep and daytime functioning (sleepiness and cognitive function) is well established. ${ }^{1}$ Shortly after wind turbines began to be erected close to housing, complaints emerged of adverse effects on health. Sleep disturbance was the main complaint. ${ }^{2}$ Such reports have been dismissed as being subjective and anecdotal, but experts contend that the quantity, consistency, and ubiquity of the complaints constitute epidemiological evidence of a strong link between wind turbine noise, ill health, and disruption of sleep. ${ }^{3}$

The noise emitted by a typical onshore $2.5 \mathrm{MW}$ wind turbine has two main components. A dynamo mounted on an $80 \mathrm{~m}$ tower is driven through a gear train by blades as long as $45 \mathrm{~m}$, and this generates both gear train noise and aerodynamic noise as the blades pass through the air, causing vortices to be shed from the edges. Wind constantly changes its velocity and direction, which means that the inflowing airstream is rarely stable. In addition, wind velocity increases with height (wind shear), especially at night, and there may be inflow turbulence from nearby structures-in particular, other turbines. This results in an impulsive noise, which is variously described as "swishing" and "thumping," and which is much more annoying than other sources of environmental noise and is poorly masked by ambient noise. ${ }^{45}$

Permitted external noise levels and setback distances vary between countries. UK guidance, ETSU-R-97, published in 1997 and not reviewed since, permits a night time noise level of $42 \mathrm{dBA}$, or $5 \mathrm{dBA}$ above ambient noise level, whichever is the greater. This means that turbines must be set back by a minimum distance of $350-500 \mathrm{~m}$, depending on the terrain and the turbines, from human habitation.
The aerodynamic noise generated by wind turbines has a large low frequency and infrasound component that is attenuated less with distance than higher frequency noise. Current noise measurement techniques and metrics tend to obscure the contribution of impulsive low frequency noise and infrasound. ${ }^{6}$ A laboratory study has shown that low frequency noise is considerably more annoying than higher frequency noise and is harmful to health - it can cause nausea, headaches, disturbed sleep, and cognitive and psychological impairment. ${ }^{7}$ A cochlear mechanism has been proposed that outlines how infrasound, previously disregarded because it is below the auditory threshold, could affect humans and contribute to adverse effects. ${ }^{8}$

Sixteen per cent of surveyed respondents who lived where calculated outdoor turbine noise exposures exceeded $35 \mathrm{~dB}$ LAeq (LAeq, the constant sound level that, in a given time period, would convey the same sound energy as the actual time varying sound level, weighted to approximate the response of the human ear) reported disturbed sleep. ${ }^{4}$ A questionnaire survey concluded that turbine noise was more annoying at night, and that interrupted sleep and difficulty in returning to sleep increased with calculated noise level. ${ }^{9}$ Even at the lowest noise levels, $20 \%$ of respondents reported disturbed sleep at least one night a month. In a meta-analysis of three European datasets $(n=1764),{ }^{10}$ sleep disturbance clearly increased with higher calculated noise levels in two of the three studies.

In a survey of people residing in the vicinity of two US wind farms, those living within 375-1400 m reported worse sleep and more daytime sleepiness, in addition to having lower summary scores on the mental component of the short form 36 health survey than those who lived 3-6.6 km from a turbine. Modelled dose-response curves of both sleep and health scores against distance from nearest turbine were significantly related after controlling for sex, age, and household clustering, with a sharp increase in effects between $1 \mathrm{~km}$ and $2 \mathrm{~km} .{ }^{11}$ A New Zealand survey showed lower health related quality of life, especially sleep disturbance, in people who lived less than $2 \mathrm{~km}$ from turbines. ${ }^{12}$

A large body of evidence now exists to suggest that wind turbines disturb sleep and impair health at distances and external noise levels that are permitted in most jurisdictions, including 
the United Kingdom. Sleep disturbance may be a particular problem in children, ${ }^{1}$ and it may have important implications for public health. When seeking to generate renewable energy through wind, governments must ensure that the public will not suffer harm from additional ambient noise. Robust independent research into the health effects of existing wind farms is long overdue, as is an independent review of existing evidence and guidance on acceptable noise levels.

Competing interests: Both authors have completed the ICMJE uniform disclosure form at www.icmje.org/coi_disclosure.pdf (available on request from the corresponding author) and declare: no support from any organisation for the submitted work; no financial relationships with any organisations that might have an interest in the submitted work in the previous three years; $\mathrm{CDH}$ has given expert evidence on the effects of wind turbine noise on sleep and health at wind farm planning inquiries in the UK and Canada but has derived no personal benefit; he is a member of the board of the Society for Wind Vigilance; AE has written letters of objection on health grounds to wind farm planning applications in Ireland.

Provenance and peer review: Not commissioned; externally peer reviewed.

1 WHO. Burden of disease from environmental noise. 2011. www.euro.who.int/ data/ assets/pdf_file/0008/136466/e94888.pdf.
2 Krogh C, Gillis L, Kouwen N, Aramini J. WindVOiCe, a self-reporting survey: adverse health effects, industrial wind turbines, and the need for vigilance monitoring. Bull Sci Tech Soc 2011;31:334-9.

3 Phillips C. Properly interpreting the epidemiologic evidence about the health effects of industrial wind turbines on nearby residents. Bull Sci Tech Soc 2011;31:303-8.

4 Pedersen E, Persson Waye K. Perception and annoyance due to wind turbine noise-a dose-response relationship. J Acoust Soc Am 2004;116:3460-70.

5 Pedersen $\mathrm{E}$, van den Berg F, Bakker R, Bouma J. Can road traffic mask sound from wind turbines? Response to wind turbine sound at different levels of road traffic sound. Energy turbines? Response to wind

6 Bray W, James R. Dynamic measurements of wind turbine acoustic signals, employing sound quality engineering methods considering the time and frequency sensitivities of human perception. Proceedings of Noise-Con 2011, Portland, Oregon, 25-27 July 2011. Curran Associates, 2011

7 Møller M, Pedersen C. Low frequency noise from large wind turbines. J Acoust Soc Am 2010;129:3727-44.

8 Salt A, Kaltenbach J. Infrasound from wind turbines could affect humans. Bull Sci Tech Soc 2011;31:296-303.

9 Van den Berg G, Pedersen E, Bouma J, Bakker R. Project WINDFARMperception. Visual and acoustic impact of wind turbine farms on residents. FP6-2005-Science-and-Society-20. Specific support action project no 044628,2008 . www.rug.nl/wewi/deWetenschapswinkels/ Specific support action project no 044628 ,
natuurkunde/publicaties/WFp-final-1.pdf.

10 Pedersen E. Effects of wind turbine noise on humans. Proceedings of the Third International Meeting on Wind Turbine Noise, Aalborg Denmark 17-19 June 2009. www. confweb.org/wtn2009/.

11 Nissenbaum M, Aramini J, Hanning C. Adverse health effects of industrial wind turbines: a preliminary report. Proceedings of 10 th International Congress on Noise as a Public Health Problem (ICBEN), 2011, London, UK. Curran Associates, 2011.

12 Shepherd D, McBride D, Welch D, Dirks K, Hill E. Evaluating the impact of wind turbine noise on health related quality of life. Noise Health 2011;13:333-9.

Cite this as: BMJ 2012;344:e1527

(c) BMJ Publishing Group Ltd 2012 